\title{
Mechanism of immunopotentiation and safety of aluminum adjuvants
}

\section{Harm HogenEsch*}

Department of Comparative Pathobiology, College of Veterinary Medicine, Purdue University, West Lafayette, IN, USA

\section{Edited by:}

Swapan K. Ghosh, Indiana State

University, USA

\section{Reviewed by:}

Swapan K. Ghosh, Indiana State University, USA

Jagadeesh Bayry, Institut National de la Santé et de la Recherche Médicale France

\section{*Correspondence:}

Harm HogenEsch, Department of Comparative Pathobiology, College of Veterinary Medicine, Purdue

University, 725 Harrison Street, West Lafayette, IN 47907, USA

e-mail: hogenesch@purdue.edu
Aluminum-containing adjuvants are widely used in preventive vaccines against infectious diseases and in preparations for allergy immunotherapy. The mechanism by which they enhance the immune response remains poorly understood. Aluminum adjuvants selectively stimulate a Th2 immune response upon injection of mice and a mixed response in human beings. They support activation of CD8 T cells, but these cells do not undergo terminal differentiation to cytotoxic T cells. Adsorption of antigens to aluminum adjuvants enhances the immune response by facilitating phagocytosis and slowing the diffusion of antigens from the injection site which allows time for inflammatory cells to accumulate. The adsorptive strength is important as high affinity interactions interfere with the immune response. Adsorption can also affect the physical and chemical stability of antigens. Aluminum adjuvants activate dendritic cells via direct and indirect mechanisms. Phagocytosis of aluminum adjuvants followed by disruption of the phagolysosome activates NLRP3inflammasomes resulting in the release of active IL-1 $\beta$ and IL-18. Aluminum adjuvants also activate dendritic cells by binding to membrane lipid rafts. Injection of aluminum-adjuvanted vaccines causes the release of uric acid, DNA, and ATP from damaged cells which in turn activate dendritic cells. The use of aluminum adjuvant is limited by weak stimulation of cell-mediated immunity. This can be enhanced by addition of other immunomodulatory molecules. Adsorption of these molecules is determined by the same mechanisms that control adsorption of antigens and can affect the efficacy of such combination adjuvants. The widespread use of aluminum adjuvants can be attributed in part to the excellent safety record based on a 70-year history of use. They cause local inflammation at the injection site, but also reduce the severity of systemic and local reactions by binding biologically active molecules in vaccines.

Keywords: adjuvants, aluminum compounds, aluminum hydroxide, inflammasomes, inflammation, dendritic cells

\section{INTRODUCTION}

Adjuvants are substances added to vaccines to enhance and direct the immune response. They are often necessary for the induction of a protective immune response against recombinant subunit antigens and protein toxins. The immunostimulatory effect of aluminum-containing adjuvants was first described in 1926 (Glenny et al., 1926). The investigators demonstrated that injection of diphtheria toxoid precipitated with alum (potassium aluminum sulfate) induced a stronger antibody response than soluble toxoid in guinea pigs. Subsequent studies showed that alumprecipitated diphtheria toxoid and tetanus toxoid also enhance protective immune responses in people (Jones, 1936; Volk and Bunney, 1942). Aluminum adjuvants are currently used in several human vaccines against infectious diseases, including vaccines against diphtheria, tetanus, pertussis, hepatitis B, anthrax, and diseases caused by Haemophilus influenzae and human papilloma virus (Baylor et al., 2002; Frazer et al., 2011). They are also used in immunotherapy for allergic diseases (Francis and Durham, 2004; Eifan et al., 2011), and are being evaluated for immunotherapy against autoimmune diabetes mellitus (Wherrett et al., 2011). Certain veterinary vaccines for protection of food animals and companion animals from infectious diseases are formulated with aluminum adjuvants (Lindblad, 2004).

Vaccines containing aluminum adjuvants induce an effective immune response that is primarily antibody-mediated. In spite of their longstanding use, the mechanism by which aluminum adjuvants selectively enhance the immune response is poorly understood. It is now generally accepted that the innate immune system plays a critical role in initiating and directing the adaptive immune response. Adjuvants enhance the adaptive immune response by activation of innate immune cells that in turn provides signals for activation of lymphocytes. Studies over the past decade have shed new light on the interaction of aluminum adjuvants with antigen-presenting cells and inflammatory cells, both of which appear to be critical in inducing and shaping the immune response. The possible mechanisms by which aluminum adjuvants enhance the immune response have been subject of several recent reviews (Aimanianda et al., 2009; Marrack et al., 2009; Kool et al., 2012). I will review the physical and chemical characteristics of aluminum adjuvants and their interaction with antigens and other immunomodulatory molecules, and discuss this along with the mechanism of immunostimulation. Aluminum adjuvants owe 
their popularity in part to their relatively low cost and long standing safety record (Lindblad, 2004). This review will conclude with a brief discussion of the safety of aluminum adjuvants.

\section{WHAT ARE ALUMINUM-CONTAINING ADJUVANTS?}

Aluminum-containing adjuvants are often simply referred to as "alum." This term should be avoided for two reasons. First, alum is the name of a specific chemical compound, hydrated potassium aluminum sulfate, $\mathrm{KAl}\left(\mathrm{SO}_{4}\right)_{2} \cdot 12 \mathrm{H}_{2} \mathrm{O}$. Precipitation of a solution of alum and antigen was originally used for the preparation of aluminum-adjuvanted vaccines. The chemical composition of the aluminum precipitate depends on the type of ions present in the antigen solution. The precipitation method is difficult to reproduce in a consistent manner and has largely been replaced by adsorption of antigens to aluminum-containing gels. The second reason to avoid the term alum is that it fails to specify which type of aluminum-containing adjuvant was used for the vaccine preparation. The two main types of aluminum adjuvants that are commercially available are aluminum hydroxide adjuvant $(\mathrm{AH})$ and aluminum phosphate adjuvant (AP). The physical and chemical composition of $\mathrm{AH}$ and AP are quite different and this has important implications for the formulation with antigens (Shirodkar et al., 1990; Lindblad, 2004; Hem and HogenEsch, 2007). $\mathrm{AH}$ is chemically aluminum oxyhydroxide, $\mathrm{Al}(\mathrm{O}) \mathrm{OH}$, rather than $\mathrm{Al}(\mathrm{OH})_{3}$. It has a crystalline structure and is composed of primary needle-like nanoparticles that are $4.5 \mathrm{~nm} \times 2.2 \mathrm{~nm} \times 10 \mathrm{~nm}$ in size (Johnston et al., 2002). The nanoparticles form loose aggregates that can be up to $17 \mu \mathrm{m}$ in size (Morefield et al., 2005). The surface area of AH is extremely large, estimated at $510 \mathrm{~m}^{2} / \mathrm{g}$ (Johnston et al., 2002). The point-of-zero charge (PZC) of AH is 11.4 giving the surface a positive charge at neutral $\mathrm{pH}$. The other commercially available aluminum adjuvant is AP, which is chemically aluminum hydroxyphosphate, $\mathrm{Al}(\mathrm{OH})_{x}\left(\mathrm{PO}_{4}\right)_{y}$. The ratio of surface hydroxyls and phosphate varies depending on the manufacturing conditions resulting in a PZC that varies between 4.5 and 5.5 and a negative charge at neutral $\mathrm{pH}$. In contrast to the crystalline structure of AH, AP is amorphous by X-ray diffraction analysis (Burrell et al., 2000a). The primary AP particles are plate-like, $50 \mathrm{~nm}$ in diameter, and form loose aggregates that are approximately $3 \mu \mathrm{m}$ in size (Burrell et al., 2000b; Morefield et al., 2005). The opposite surface charges of $\mathrm{AH}$ and $\mathrm{AP}$ in the $\mathrm{pH}$ range used for vaccine formulations affect the electrostatic interactions between the adjuvants and vaccine antigens as discussed in more detail below. Another difference between AH and AP is that AP more readily dissolves following injection. This was demonstrated in vivo with ${ }^{26} \mathrm{Al}$-labeled $\mathrm{AH}$ and $\mathrm{AP}$ injected intramuscularly into rabbits. Analysis of blood and tissue samples over a 28 day period revealed that about three times as much ${ }^{26} \mathrm{Al}$ was released from $\mathrm{AP}$ than from AH (Flarend et al., 1997).

Another commercially available aluminum-containing adjuvant is Imject ${ }^{\circledR}$ Alum. It is commonly used for experimental and basic immunological studies, but it is chemically very different from the $\mathrm{AH}$ and $\mathrm{AP}$ adjuvants that are used in human and veterinary vaccines. Imject ${ }^{\circledR}$ Alum consists of crystalline magnesium hydroxide $(40 \mathrm{mg} / \mathrm{mL})$ and amorphous aluminum hydroxycarbonate ( $40 \mathrm{mg} / \mathrm{mL}$; Hem et al., 2007). The composition of the aluminum component is different from $\mathrm{AH}$ and $\mathrm{AP}$, while magnesium by itself has effects on the immune system and inflammatory response (Exley et al., 2010). Magnesium ions inhibit macrophage activation by blocking certain calcium channels and this contributes to the anti-inflammatory effect of magnesium (Lee et al., 2011). While Imject ${ }^{\circledR}$ Alum clearly has adjuvant activity, it should not be used in experiments aimed at elucidating the mechanism of aluminum adjuvants in licensed human vaccines.

\section{IMMUNOSTIMULATION BY ALUMINUM-CONTAINING ADJUVANTS}

Highly purified vaccine antigens are usually poorly immunogenic because of insufficient stimulation of the innate immune system. Aluminum adjuvants are included in vaccines to enhance the immune response to purified viral and bacterial antigens such as hepatitis B surface antigen (HBsAg), human papilloma virus capsid proteins and inactivated bacterial toxins. Their incorporation in vaccine formulations increases the concentration and avidity of antigen-specific antibodies (Petty and Steward, 1977; Lefeber et al., 2003). The level of immunity that is obtained by vaccination varies markedly among individuals due to genetically determined polymorphisms in molecules that play a role in the immune response, stochastic variation in the repertoire of antigen-specific receptors, and non-genetic factors such as age, nutritional status, and environmental influences. Adjuvants increase the proportion of the vaccinated population that develops a protective immune response and the duration of the immune response, and may allow for fewer immunizations and a reduced amount of antigen per dose (Coffman et al., 2010). Adjuvants also shape the type of immune response that develops in response to the antigens included in the vaccine. Aluminum adjuvants primarily enhance antibody production and have little effect on the cell-mediated arm of the immune response. Recent studies have begun to shed light on the complex mechanisms that appear to underlie the immunostimulatory effect of aluminum adjuvants. In reviewing these studies, one should keep in mind that many experiments were carried out using intraperitoneal injections of Imject ${ }^{\circledR}$ Alum in a few inbred strains of mice. Although elegant and informative in terms of the biology, the relevance to the mechanisms involved in the immune response to aluminum adjuvants injected intramuscularly in human beings remains to be determined.

\section{THE IMMUNE RESPONSE TO ALUMINUM-ADJUVANTED VACCINES}

Immunization with aluminum-adjuvanted vaccines induces antibody-mediated protection directed by CD4 T cells. Naïve CD4 $\mathrm{T}$ cells differentiate into effector cells with specific functions based on molecular signals provided by dendritic cells and the local microenvironment in which the differentiation takes place. There is considerable plasticity among effector CD4 T cells, but they can be divided into subpopulations based on secretion of particular combinations of cytokines and on expression of distinct surface markers and transcription factors (Zhu et al., 2010; Okoye and Wilson, 2011). The effector CD4 T cells were initially divided into Th1 and Th2 cells (Mosmann et al., 1986). Th1 cells are characterized by the secretion of IFN- $\gamma$ and expression of the transcription factor T-bet, and Th2 cells by the secretion of IL-4, IL-5, and IL13, and the expression of GATA-3 (Zhu et al., 2010). Around 2003, 
two new subpopulations of CD4 effector T cells were recognized, namely Th17 cells which secrete the cytokines IL-17A and IL-22 and express ROR $\gamma \mathrm{t}$, and inducible regulatory $\mathrm{T}$ cells (iTreg) that express Foxp3 (Zhu et al., 2010). More recently, follicular T helper cells $\left(\mathrm{T}_{\mathrm{FH}}\right)$ were identified as a separate $\mathrm{CD} 4 \mathrm{~T}$ cell subpopulation based on the expression of CXCR5, PD1, and the transcription factor BCL-6 (Johnston et al., 2009; Nurieva et al., 2009; Yu et al., 2009). These studies suggested that $\mathrm{T}_{\mathrm{FH}}$ rather than $\mathrm{Th} 2$ cells are critical for antibody-mediated immune responses. Earlier reports showed that aluminum adjuvants direct differentiation of CD4 $\mathrm{T}$ cells to Th2 effector cells in vivo and in vitro and do not support the differentiation of Th1 cells (Brewer et al., 1996; Comoy et al., 1997; Cunningham et al., 2004; Sokolovska et al., 2007). The ability of aluminum adjuvants to induce a Th2-biased immune response is the basis of the common use of these adjuvants in the induction of allergic diseases in mouse models. More recent studies showed that injection of mice with alum-precipitated protein induced a marked increase of antigen-specific $\mathrm{T}_{\mathrm{FH}}$ cells in the draining lymph nodes (Serre et al., 2011a,b). Comparison of $\mathrm{T}_{\mathrm{FH}}$ and non- $\mathrm{T}_{\mathrm{FH}} \mathrm{CD} 4 \mathrm{~T}$ cells suggested that $\mathrm{T}_{\mathrm{FH}}$ cells rather than $\mathrm{Th} 2$ cells were the major subpopulation of IL-4-secreting CD4 T cells (Serre et al., 2011a). Taken together these older and more recent studies suggest that aluminum adjuvants induce the differentiation of Th2 cells that drive an eosinophilic inflammatory response and $\mathrm{T}_{\mathrm{FH}}$ cells that stimulate antibody production. In addition aluminum-adjuvanted vaccines may support the differentiation of Th17 cells in mice. These cells are thought to be important in the protection against extracellular bacterial and fungal infections. A vaccine containing a yeast-expressed recombinant protein with AH induced protection against Staphylococcus aureus and Candida albicans. Protection was dependent on IL-17A and induction of Th17 cells in draining lymph nodes was demonstrated (Lin et al., 2009). A whole cell Streptococcus pneumoniae vaccine formulated with $\mathrm{AH}$ induced a robust IL-17A response in mice (HogenEsch et al., 2011). This response was not observed with AP or in the absence of AH. Earlier work had indicated that IL-17A is critical for protection against colonization following vaccination (Lu et al., 2008). These two examples of AH-supported Th17 induction used either a very high dose $(300 \mu \mathrm{g})$ of a highly mannosylated protein or a poorly defined mixture of antigens. It remains to be seen if aluminum adjuvants support Th17 differentiation when combined with more conventional protein antigens. Interestingly, the induction of Th17 differentiation can be driven by IL-1 and IL-18 (Conforti-Andreoni et al., 2011), two cytokines that are induced by aluminum adjuvants as discussed in more detail below.

Evidence for a Th2-biased immune response in people is less convincing and the few available studies suggest a response driven by a mixed population of Th1, Th2, and possibly other CD4 effector cells. Peripheral blood mononuclear cells (PBMC) isolated from individuals immunized with keyhole limpet hemocyanin (KLH) combined with AH secreted mostly IL-5, IL-10, and IL-13 upon restimulation in vitro and induced IgG1 and IgG4 anti-KLH antibodies consistent with a Th2 response (Spazierer et al., 2009). However, restimulation of PBMC from the same volunteers with tetanus toxoid induced IFN- $\gamma$ secretion and no IL-13 suggestive of a Th1 response. Although the vaccination and natural exposure histories were not specified, most tetanus vaccines contain aluminum adjuvants suggesting that aluminumadjuvanted tetanus vaccines stimulated a Th1-biased response. Aluminum adjuvants are also used in immunotherapy of autoimmune and allergic diseases. Two subcutaneous injections of the $65 \mathrm{kDa}$ isoform of glutamic acid dehydrogenase 65 (GAD65), an autoantigen in type 1 diabetes mellitus, formulated with $\mathrm{AH}$ ( $0.5 \mathrm{mg}$ aluminum/dose) induced an antibody and $\mathrm{T}$ cell response. The $\mathrm{T}$ cell response was mixed with a significant increase of ex vivo secretion of IFN- $\gamma$, IL-17, IL-10, and type 2 cytokines, and development of FoxP3+, CD25+ CD4 T cells (Ludvigsson et al., 2008; Hjorth et al., 2011). A phase II clinical trial of GAD65 with $\mathrm{AH}$ failed to show efficacy in halting or delaying the development of diabetes mellitus (Wherrett et al., 2011). Preparations of allergens with aluminum hydroxide adjuvant are widely used for subcutaneous desensitization of patients with allergies (Francis and Durham, 2004). Possible explanations for the effect of this treatment include a shift away from Th2 responses and induction of IgE-blocking IgG antibodies and regulatory T cells (Eifan et al., 2011). In vitro exposure of PBMC from allergic individuals to allergen and aluminum hydroxide adjuvant reduced the secretion of IL-5 and IL-13 in comparison with allergen only, while the adjuvant had little effect on the secretion of IL-10, IL-12, and IFN- $\gamma$ (Wilcock et al., 2004).

Proteins taken up by antigen-presenting cells are typically processed and peptides presented via MHC II molecules to CD4 $\mathrm{T}$ cells. In some cases, peptides from extracellular proteins can enter the MHC I presentation pathway and be presented to CD8 T cells. Dendritic cells are most efficient among antigen-presenting cells in cross-presentation of antigens (Joffre et al., 2012). The mechanisms involved in cross-presentation are not completely understood and vary depending on the antigen and delivery system (Compeer et al., 2012; Joffre et al., 2012). Immunization of mice with aluminum-adjuvanted vaccines does not effectively prime the development of cytotoxic T cells (CTLs; Dillon et al., 1992; Kwissa et al., 2003; Garulli et al., 2008). However, following immunization of ovalbumin (OVA) with AH or alum-precipitated OVA, OVAspecific CD8 T cells are activated and proliferate. The activated $\mathrm{T}$ cells express IFN- $\gamma$, but fail to differentiate into CTLs (McKee et al., 2009; Serre et al., 2010; MacLeod et al., 2011). Cross-presentation of OVA was dependent on CD8+ dendritic cells, a subset of DCs specialized in cross-presentation (MacLeod et al., 2011). The addition of a TLR4 agonist, monophosphoryl lipid A (MPLA), was required for induction of CTL differentiation (MacLeod et al., 2011). MPLA induces the secretion of IL-12 which is necessary for the terminal differentiation of CD8 T cells (Curtsinger et al., 2003; Pearce and Shen, 2007).

\section{ROLE OF ADSORPTION IN THE IMMUNOSTIMULATING EFFECT OF ALUMINUM ADJUVANTS}

Antigens adsorb to aluminum adjuvants via hydrophobic and van der Waals forces, via electrostatic attraction and by ligand exchange (Hem and HogenEsch, 2007). Electrostatic attraction occurs when antigen and the adjuvant surface have opposite charges. The surface of $\mathrm{AH}$ is positively charged at neutral $\mathrm{pH}$ and attracts antigens with an isoelectric point (i.e.p.) less than 7 , whereas AP is negatively charged and attracts proteins with an i.e.p. greater than 7 (Figure 1). Fusion proteins can consist 


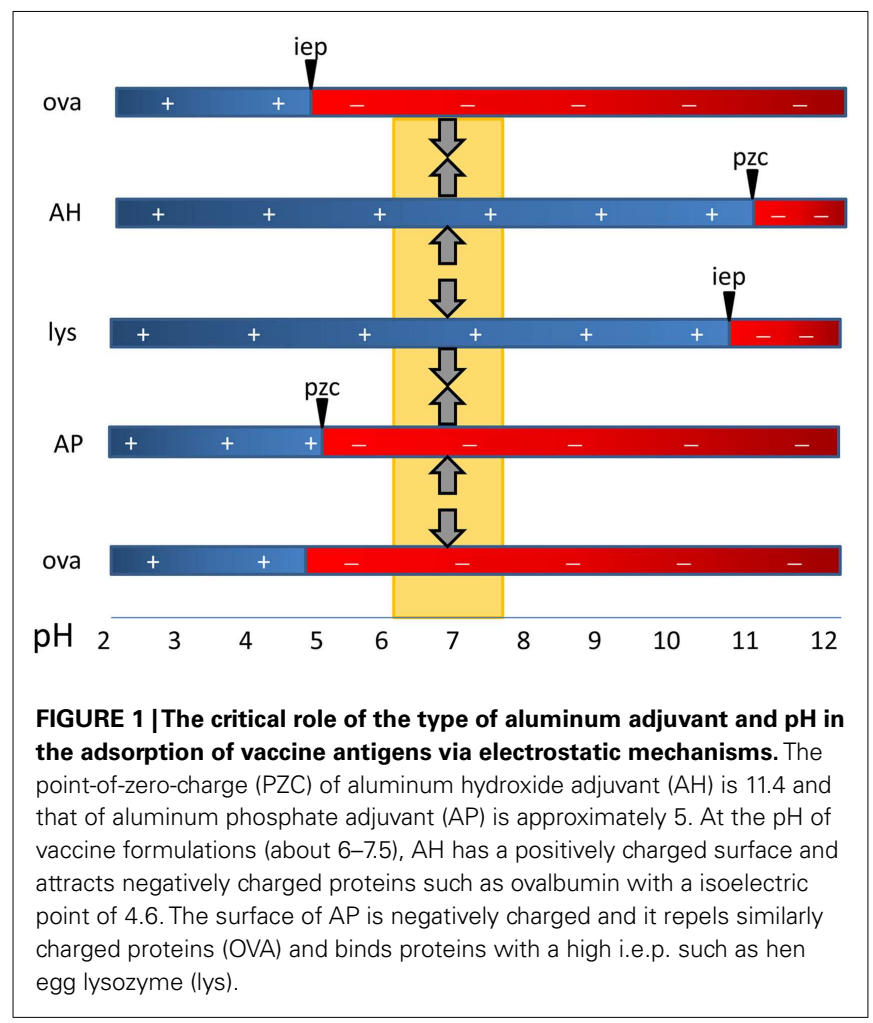

of peptides with opposite i.e.p.'s resulting in a bipolar molecule. This likely affects the orientation of the antigens on the adjuvant surface when adsorbed to AH vs. AP, but no effect on the immune response was observed (Dagouassat et al., 2001). Antigens adsorbed via electrostatic mechanisms are quickly released upon exposure to interstitial fluid (Iyer et al., 2003; de Veer et al., 2010). Ligand exchange is the strongest attractive force between antigens and aluminum adjuvants. Aluminum has a higher affinity for phosphate than for hydroxyls and phosphates will displace surface hydroxyls on aluminum adjuvants. Molecules with multiple terminal phosphate groups have a very high affinity for $\mathrm{AH}$ as they adsorb via ligand exchange. The affinity can be modulated by pre-treatment of $\mathrm{AH}$ with phosphate buffer resulting in replacement of hydroxyls by phosphates. Antigens adsorbed via ligand exchange mechanism are slowly released from the adjuvant following exposure to interstitial fluid.

Adsorption is generally thought to be important for the immunostimulatory effect of aluminum adjuvants (Gupta, 1998). The particulate nature of adsorbed antigens facilitates uptake by antigen-presenting cells via phagocytosis (Mannhalter et al., 1985; Morefield et al., 2005). Adsorbed antigens are more slowly released from the injection site (Leeling et al., 1979; Weissburg et al., 1995; Noe et al., 2010), but the kinetics are highly dependent on the strength of the adsorption. Electrostatically adsorbed antigens are rapidly released and diffuse away from the injection site at a higher rate than antigens adsorbed via ligand exchange (Noe et al., 2010). The retention of antigens at the injection site allows time for inflammatory cells and antigen-presenting cells to accumulate at the injection site and to interact with vaccine antigens. This is consistent with early experiments by Holt who demonstrated that removal of the injection site within 4 days after subcutaneous injection of guinea pigs with diphtheria toxoid adsorbed to AP interfered with the development of an antibody response. In contrast, removal of the injected ear $2 \mathrm{~h}$ after subcutaneous injection of $\mathrm{AH}$ with antigen did not affect the magnitude or duration of the immune response (Hutchison et al., 2012). This would suggest that neither adsorption nor the local inflammatory response at the injection site is necessary for the immunostimulatory effect of aluminum adjuvants. It is difficult to reconcile this with the studies by Holt. Unfortunately, the results of ear ablation were not reported following injection of antigen only. It is possible that tissue trauma resulting from resection of the ear induced sufficient inflammatory signals to stimulate the development of the immune response.

Aluminum adjuvants can also stimulate the immune response to non-adsorbed antigens (Berthold et al., 2005; Romero Mendez et al., 2007). The adjuvant and antigen need to be injected at the same site in order for the enhanced immunogenicity to occur (Chang et al., 2001; Eisenbarth et al., 2008). The need for adsorption appears to decrease with larger antigen doses (Berthold et al., 2005). This is probably caused by interactions between the antigen and the extracellular matrix resulting in retention of a portion of the injected antigen. This is indicated by the kinetics of subcutaneously injected soluble protein (Noe et al., 2010) and further supported by pharmacokinetic studies with subcutaneously injected monoclonal antibodies showing significant retention of protein at the site of injection (Joshi et al., 2006; Xu et al., 2010). In vitro experiments suggests that a variable but significant portion of monoclonal antibodies is retained at the injection site via electrostatic interactions with the extracellular matrix (Mach et al., 2011). This is also likely to happen with certain vaccine antigens. When higher doses of non-adsorbed antigens are used, a sufficient amount of antigen is retained at the injection site for interaction with inflammatory cells recruited in response to the co-injected aluminum adjuvants. On the other hand, too tight adsorption has a negative effect on the immunogenicity of the vaccine as demonstrated most clearly with alpha-casein, a small $24 \mathrm{kDa}$ protein with eight phosphate groups allowing for extensive ligand exchange interactions with AH (Hansen et al., 2007). The adsorptive strength (affinity) of alpha-casein for AH could be reduced by pre-treatment of $\mathrm{AH}$ with phosphate buffer and this resulted in an increased antibody and T cell response (Hansen et al., 2007). High adsorptive strength probably interferes with antigen processing and prevents T cell activation. Similarly, the adsorptive strength of HBsAg which is embedded in a phospholipid membrane can be reduced by pre-treatment of $\mathrm{AH}$ with phosphate. The formulation of HBsAg with phosphate-treated AH or AP induced a greater antibody response than HBsAg with AH (Kwissa et al., 2003; Hansen et al., 2009).

While adsorption to aluminum adjuvants usually enhances the immune response to antigens, it can affect the physical and chemical stability of antigens over time (Clapp et al., 2011). Proteins are subjected to various degradation processes including deamidation, oxidation, and hydrolysis that are dependent on $\mathrm{pH}$ and temperature (Manning et al., 2010). The $\mathrm{pH}$ of the microenvironment of the charged aluminum adjuvant surface is different from the bulk formulation $\mathrm{pH}$ because of attraction of ions from the 
solution. The positively charged surface of $\mathrm{AH}$ attracts negatively charged hydroxyl ions increasing the microenvironment $\mathrm{pH}$ by as much as two units (Wittayanukulluk et al., 2004). This change in $\mathrm{pH}$ can accelerate the degradation of adsorbed antigens. Proteins adsorbed onto solid surface also tend to unfold causing a loss of the secondary and tertiary structure (Manning et al., 2010). This often results in exposure of hydrophobic parts of the proteins and an increase of hydrophobic interactions with aluminum adjuvants. This likely contributes to reduced desorption of antigens from aluminum adjuvants in aged vaccines (Shi et al., 2001a; Vessely et al., 2009). Several biophysical assays including differential scanning calorimetry, intrinsic (tryptophan) and extrinsic fluorescence, and Fourier transform infrared spectroscopy, have been successfully employed in recent years to assess the conformational stability of proteins adsorbed onto aluminum adjuvants (Jones et al., 2005; Peek et al., 2007; Ausar et al., 2011; Iyer et al., 2012; Ljutic et al., 2012). Adsorption usually decreases the stability of proteins, but increased stability of $\mathrm{AH}$-adsorbed proteins was observed in a few cases (Estey et al., 2009; Iyer et al., 2012). Few studies have directly examined the effect of the adsorption-induced structural changes on the immune response to the vaccine. Studies of freshly prepared AH-adsorbed recombinant protective antigen (rPA) of Bacillus anthracis ( $\mathrm{rPA}$ ) identified minimal changes in the protein structure (Soliakov et al., 2012). However, others observed marked structural changes in rPA upon aging the vaccine for 3 weeks, and this was associated with a decrease of neutralizing antibodies in mice injected with the aged formulation compared with the freshly prepared vaccine (Wagner et al., 2012). Adsorption-induced changes in the protein structure can be reduced by formulation of the vaccine with a phosphate buffer which alters the microenvironment $\mathrm{pH}$ and may reduce the adsorptive strength (Wittayanukulluk et al., 2004; Iyer et al., 2012). An alternative strategy is to add stabilizers such as sucrose, sorbitol and trehalose to the vaccine formulation (Peek et al., 2007; Iyer et al., 2012). These compounds stabilize proteins in solution and adsorbed onto aluminum adjuvants, but their addition to vaccine formulation scan decrease the adsorption of protein antigens (Peek et al., 2007; Vessely et al., 2007).

\section{ROLE OF INFLAMMATION IN THE IMMUNOSTIMULATING EFFECT OF ALUMINUM ADJUVANTS}

Inflammation induced at the injection site is thought to be important for the adjuvant effect of AH and AP. Intramuscular injection of mice and guinea pigs with tetanus toxoid vaccines with $\mathrm{AH}$ resulted in necrosis of muscle fibers and inflammation with edema and infiltration of leukocytes (Goto and Akama, 1982; Goto et al., 1997). This is associated with increased expression of mRNAs for chemokines, cytokines, and cell adhesion molecules (Mosca et al., 2008). The majority of leukocytes were neutrophils during the first $72 \mathrm{~h}$, followed by accumulation of increasing numbers of macrophages at 1 week after injection (Goto and Akama, 1982). The macrophages form granulomas that can persist for months (Goto and Akama, 1982; Verdier et al., 2005). Although these granulomas contain aluminum adjuvant and antigen, their presence is not required for the immune response as removal of the injection site after 7 days did not interfere with the magnitude or duration of the immune response (Holt, 1950). Goto and Akama
(1982) found few eosinophils at the injection site in contrast to an earlier report that approximately $25 \%$ of the inflammatory cells were eosinophils 4 days following intramuscular injection of tetanus toxoid with AH or AP (Walls, 1977). In a more recent study, the composition of the inflammatory cells following intramuscular injection of mice with OVA and $\mathrm{AH}$ was analyzed by flow cytometry at $24 \mathrm{~h}$ after injection (Calabro et al., 2011). The majority of infiltrating cells were neutrophils and inflammatory monocytes with few eosinophils (Calabro et al., 2011). Other studies examined the kinetics of the inflammatory response following intraperitoneal injection of aluminum-containing adjuvants. This route of injection allows for recovery of cells without the need of enzymatic treatment and for quantification of the concentration of cytokines in the peritoneal fluid, but of course is different from the normal route of injection of vaccines. Injection of aluminumcontaining adjuvant with or without protein antigens such as OVA resulted in rapid secretion of chemokines and cytokines into the peritoneal fluid (Kool et al., 2008b; McKee et al., 2009; Korsholm et al., 2010). An increase of neutrophils occurred as early as $6 \mathrm{~h}$ after injection (Kool et al., 2008b; Korsholm et al., 2010). This was followed by an increased number of inflammatory monocytes and myeloid and plasmacytoid dendritic cells. The number of eosinophils was increased at $24 \mathrm{~h}$ after injection (Walls, 1977; Kool et al., 2008b; McKee et al., 2008, 2009; Korsholm et al., 2010), and continued to increase reaching a peak at 4-8 days (Walls, 1977). The 24-h accumulation of eosinophils was partially dependent on mast cell-derived IL-5 and histamine and unidentified factors secreted by macrophages (McKee et al., 2009). The increase of eosinophils in response to $\mathrm{AH}$ was diminished in thymectomized mice suggesting a role for T cells (Walls, 1977). Neutrophils orchestrate the recruitment of inflammatory monocytes via the release of granule proteins such as azurocidin and LL-37 (Soehnlein and Lindbom, 2010). In spite of this role, depletion of neutrophils with monoclonal antibodies prior to immunization with lysozyme and aluminum adjuvant increased activation of antigen-specific T cells and the antibody response (Yang et al., 2010). The neutrophils appeared to compete with antigen-presenting cells for antigen and to interfere directly with antigen presentation (Yang et al., 2010). Inflammatory monocytes recruited to the injection site can differentiate into macrophages and dendritic cells. They take up antigen and transport it to the draining lymph node while undergoing differentiation into dendritic cells. This is consistent with in vitro experiments which show that aluminum adjuvants induce differentiation of human monocytes to cells with phenotypic and functional characteristics of dendritic cells (Ulanova et al., 2001; Rimaniol et al., 2004; Seubert et al., 2008). Depletion of peritoneal macrophages with clodronate-containing liposomes did not affect the immune response to intraperitoneally injected OVA with aluminum adjuvant (McKee et al., 2009). However, depletion of dendritic cells nearly completely abolished $\mathrm{T}$ cell responses and antibody production indicating a critical role for dendritic cells in the immune response to aluminum-adjuvanted vaccines (Kool et al., 2008b). Intraperitoneal injection of aluminum adjuvant also induced an increase of Gr-1+, IL-4+ cells in the spleen, most of which are eosinophils (Jordan et al., 2004; Wang and Weller, 2008). Although these eosinophils appeared to enhance $\mathrm{B}$ cell priming and early IgM antibody production, the absence of 
eosinophils did not affect the quality or magnitude of the antibody response to aluminum-adjuvanted vaccines (McKee et al., 2009). Recently, basophils were reported to serve as antigen-presenting cells for Th2-biased immune responses (Perrigoue et al., 2009; Sokol et al., 2009; Yoshimoto et al., 2009). These reports were based on depletion of basophils with anti-FceRI (Mar-1) antibodies. It was subsequently shown that mice have a subset of FceRI+ dendritic cells that are depleted by Mar-1 antibody treatment in addition to basophils (Hammad et al., 2010). Genetically engineered mice that lack basophils are capable of mounting a normal antibody response to aluminum-adjuvanted vaccines indicating that basophils are not necessary (Ohnmacht et al., 2010). Thus, among the different cells recruited to the vaccine injection site, the recruitment of inflammatory monocytes and subsequent differentiation into dendritic cells appears to be critical for the development of the immune response to aluminum-adjuvanted vaccines.

\section{ALUMINUM ADJUVANTS AND DENDRITIC CELLS}

In vitro studies with mouse bone marrow-derived dendritic cells have demonstrated that aluminum adjuvants have a direct effect on dendritic cells. They increase the uptake of antigens and the presentation and activation of antigen-specific T cells (Morefield et al., 2005; Sokolovska et al., 2007; Ghimire et al., 2012). Both $\mathrm{AH}$ and AP induce secretion of IL- $1 \beta$ and IL-18 by dendritic cells (Li et al., 2007; Sokolovska et al., 2007). This also occurred in MyD88-deficient dendritic cells consistent with observations that immunostimulation by aluminum adjuvants in vivo was independent of signaling through Toll-like receptors (Schnare et al., 2001; Gavin et al., 2006). Dendritic cells incubated with aluminum adjuvants and OVA induced differentiation of naïve OVA-specific CD4 $\mathrm{T}$ cells to Th2 cells in vitro. This effect was blocked by antibodies against IL-1 $\beta$ and IL-18 suggesting a role for these cytokines in Th2 differentiation (Sokolovska et al., 2007). IL-1 $\beta$ and IL-18 are synthesized by cells as inactive cytoplasmic precursors that require cleavage by the enzyme caspase- 1 in order to be released from the cells. Experiments with caspase-1 inhibitors demonstrated that aluminum adjuvants induce activation of caspase- 1 resulting in the secretion of the active forms of IL- $1 \beta$ and IL-18 (Li et al., 2007; Sokolovska et al., 2007). Subsequent work showed that the secretion of IL-1 $\beta$ and IL-18 by dendritic cells incubated with aluminum adjuvants depends on the presence of the NODlike receptor NLRP3 (Eisenbarth et al., 2008; Franchi and Nunez, 2008; Hornung et al., 2008; Kool et al., 2008a; Li et al., 2008). NLRP3 is a member of a family of cytoplasmic pattern recognition receptors and is activated in response to a variety of sterile stimuli such as ATP, uric acid crystals, silica, asbestos, and aluminum adjuvants (Martinon et al., 2009). Upon activation, NLRP3 forms a multimeric protein complex termed inflammasome that contains the adaptor protein apoptosis-associated speck-like protein (ASC) and the inactive precursor of caspase-1, procaspase-1. The close proximity of procaspase-1 molecules leads to autoproteolytic processing into active caspase- 1 that in turn cleaves pro-IL-1 $\beta$ and pro-IL-18 into their active and secreted forms (Martinon et al., 2009). Activation of NLRP3 by aluminum adjuvants required phagocytosis of aluminum particles, acidification of lysosomes, and maturation of cathepsin B (Eisenbarth et al.,
2008; Hornung et al., 2008). The aluminum particles caused disruption of the phagolysosomes and release of active cathepsin B into the cytoplasm which may be a sufficient signal for NLPR3 activation (Hornung et al., 2008). Phagocytosis and activation of cathepsin B in dendritic cells and macrophages can also lead to discharge of ATP via connexin and pannexin channels into the extracellular environment (Riteau et al., 2012). The extracellular ATP in turn binds to purinergic receptors including the P2X7 receptor which induces inflammasome activation. The in vivo relevance of caspase- 1 and NLRP3-dependent secretion of IL- $1 \beta$ and IL-18 in the immunostimulatory effect of aluminum adjuvants is controversial. Experiments with NLRP3-deficient mice have demonstrated a marked suppression of antigen-specific IgE and IgG1 production (Eisenbarth et al., 2008; Li et al., 2008), suppression of IgE, but not IgG1 (Kool et al., 2008a), or no effect on antibody production at all (Franchi and Nunez, 2008; McKee et al., 2009). It is likely that these divergent results reflect differences in immunization protocols, type and amount of aluminum adjuvants, and mouse strains. Aluminum adjuvants also induce the secretion of IL- $1 \alpha$ by dendritic cells in a caspase-1-dependent manner (Sharp et al., 2009). IL- $1 \alpha$ and IL- $1 \beta$ bind to the same IL-1 receptor and have overlapping functions. However, the secretion of IL- $1 \alpha$ was only partially dependent on phagocytosis and NLRP3 suggesting that a different pathway is involved in the secretion of this cytokine (Sharp et al., 2009). IL-1 $\alpha$, IL-1 $\beta$, and IL-18 signaling requires the adaptor protein MyD88 (Adachi et al., 1998). The adjuvant effect of aluminum adjuvants in vivo is independent of MyD88 suggesting a limited role for these cytokines in immunostimulation by AH and AP (Schnare et al., 2001; Gavin et al., 2006).

Another possible mechanism of dendritic cell activation by aluminum adjuvants is binding to plasma membrane lipids. This led to reassortment of lipids and aggregation of lipid rafts resulting in activation of the syk kinase and phosphoinositide-3 kinase (PI3K) pathways (Flach et al., 2011). The lipid sorting resulted in abortive phagocytosis and uptake of antigen, but not the aluminum adjuvant. The authors suggested that the uptake of antigen via endocytosis without adjuvant prevents cross-presentation and would explain the ability of aluminum adjuvants to induce a humoral and CD4 T cell response, but not a CTL response. However, as discussed above, proteins combined with aluminum adjuvants can in fact activate CD8 T cells (Kwissa et al., 2003; Serre et al., 2010; MacLeod et al., 2011). Moreover, there is abundant evidence of intracellular localization of aluminum in macrophages and dendritic cells, both in vitro and in vivo (Rimaniol et al., 2004; Morefield et al., 2005, 2008). Activation of PI3K also occurs following binding of ATP to the P2X7 receptor and is required for inflammasome activation by extracellular ATP (Cruz et al., 2007). Inhibition of PI3K partially inhibited the secretion of IL- $1 \beta$ by dendritic cells (Mori et al., 2012).

Incubation of lipopolysaccharide (LPS)-activated macrophages with aluminum adjuvants induced secretion of prostaglandin E2 (PGE2; Kuroda et al., 2011). Damage of phagolysosomes by phagocytized aluminum particles caused activation of Syk and p38 MAP kinase pathways leading to the synthesis of PGE2. Prostaglandin E synthase-deficient mice immunized with OVA and aluminum adjuvant had decreased production of 
OVA-specific IgE, whereas the production of IgG1 and IgG2 $\mathrm{c}$ were similar to wild-type mice.

In addition to direct effects on dendritic cells, aluminum adjuvants can also have indirect effects via endogenous activators. Cell injury and necrosis cause the release of intracellular molecules that activate innate immune cells. These molecules have been termed alarmins or danger-associated molecular patterns, and include High Mobility Group Box 1 (HMGB1), uric acid, ATP, heat shock proteins, DNA, IL-1 $\alpha$, and filamentous actin (Rock et al., 2010; Ahrens et al., 2012; Zhang et al., 2012). Several recent studies have suggested that uric acid, DNA, ATP, and HSP70 are involved in the immunostimulation by aluminum adjuvants (Kool et al., 2008b; Marichal et al., 2011; Riteau et al., 2012; Wang et al., 2012). Intraperitoneal injection of aluminum-containing adjuvant induced an increase of uric acid, and treatment of mice with uricase decreased activation of antigen-specific $\mathrm{T}$ cells in the draining lymph node suggesting a role for uric acid in the activation of the immune response by aluminum-containing adjuvants (Kool et al., 2008b). Aluminum adjuvants are commonly used for sensitization of mice in the establishment of mouse models of allergic airway disease. The induction of allergic airway disease was impaired upon treatment with uricase implying a role of uric acid in the development of the aluminum adjuvant induced allergic immune response (Kool et al., 2011). However, as discussed above, aluminum adjuvants induce a weak cytotoxic $\mathrm{T}$ cell response by themselves, whereas uric acid is a potent inducer of CTLs (Shi et al., 2003). Moreover, the role of uric acid following intramuscular injection of aluminum adjuvants remains to be determined. Both intraperitoneal and intramuscular injection of aluminum adjuvants with OVA induced cell death and release of DNA (Marichal et al., 2011). OVA-specific secretion of IgE and IgG1 following intraperitoneal injection was inhibited by treatment with DNAse around the time of injection. Host cell DNA itself acted as an adjuvant, and activated Th2 immune responses via the transcription factor interferon regulatory factor 3 (IRF3). Injection of IRF3-deficient mice with aluminum adjuvant induced similar accumulation of inflammatory cells in the peritoneal cavity and OVA-specific IgG1 as wild-type mice, but IRF3-deficiency abolished the OVA-specific IgE response (Marichal et al., 2011), suggesting a dissociation of the IgG1 and IgE response. Subcutaneous injection of aluminum-adjuvanted-OVA induced increased expression of membrane HSP70 in splenic dendritic cells (Wang et al., 2012). A similar effect was seen upon administration of OVA with known stress-inducing compounds. Inhibition of the function of HSP70 with a small molecule inhibitor in mice only decreased the IgG2a response which suggests that HSP70 is primarily involved with the induction of the weak Th1-component of the immune response to aluminum-adjuvanted vaccines in mice. This is consistent with the induction of predominant Th1 responses with HSP70 (Wang et al., 2002). Furthermore, HSP70 is a ligand of TLR4 (Vabulas et al., 2002), whereas the antibody response to aluminum-adjuvanted vaccines is independent of TLRs (Schnare et al., 2001; Gavin et al., 2006). This suggests a minimal role of HSP70 in the immunostimulation by aluminum adjuvants.

In summary, the formulation of vaccines with aluminum adjuvants activate dendritic cells both directly and indirectly leading to the differentiation of CD4 T cells into effector cells (Figure 2). The relative roles of the direct and indirect mechanisms depend on several factors, including the dose of aluminum in the vaccine, dose volume, and route of injection.

\section{ALUMINUM IN COMBINATION ADJUVANTS}

A weakness of aluminum adjuvants is the failure to induce a robust cell-mediated immune response which limits its utility in vaccines for diseases in which such an immune response is protective. The addition of other immunostimulatory molecules to vaccines can potentially overcome this limitation. The goal of such combination adjuvants is to develop the "perfect mix" to achieve the desired type and magnitude of an immune response (Guy, 2007). When aluminum adjuvants are combined with other immunostimulatory molecules, the interactions are subject to the same mechanisms that are involved with adsorption of antigens. The adsorbed molecules are retained at the injection site which can prevent potential systemic toxicity while increasing the interactions with newly recruited antigen-presenting cells. However, too tight adsorption through ligand exchange interferes with the activity of the immunostimulatory molecules such as LPS and CpG oligonucleotides (ODN; Shi et al., 2001b; Aebig et al., 2007). Adsorption of immunostimulatory molecules to aluminum adjuvants can also affect the adsorption of antigens (Aebig et al., 2007). Thorough optimization of the formulation conditions is necessary to achieve the most effective vaccine combination.

As aluminum adjuvants do not activate TLRs, the addition of TLR agonists is a logical choice. A combination adjuvant composed of AH and the TLR4 agonist MPLA is used in licensed vaccines against hepatitis $B$ and human papilloma virus (Garcon, 2010). MPLA is a derivative of LPS with greatly reduced toxicity. LPS has two phosphates which allow binding with high affinity to AH via ligand exchange and this neutralizes the activity of LPS (Shi et al., 2001b). As the name implies, MPLA has one phosphate which reduces the affinity for $\mathrm{AH}$ and enhances the adjuvant effect of AH. The combination of AH with MPLA induces a stronger antibody response and a shift from Th2 to Th1 cytokine production in spleen cells (Giannini et al., 2006; Didierlaurent et al., 2009). As mentioned earlier, the addition of MPLA to AH also enables differentiation of activated CD8 T cells into CTLs (MacLeod et al., 2011). The effect of other TLR agonists on the immune response to aluminum-adjuvanted vaccines has been investigated, but this has not yet led to licensed products. The TLR9 agonist CpG ODN enhanced the antibody response in mice to hepatitis $\mathrm{B}$ antigen formulated with AH with a shift from IgG1 to IgG2a antibodies, and induced a CTL response (Davis et al., 1998). A similar enhancement has been reported in people injected with $\mathrm{AH}$-adjuvanted hepatitis B vaccine with added CpG ODN (Cooper et al., 2004). The CpG ODN bind more strongly to $\mathrm{AH}$ than $\mathrm{AP}$ and the binding to $\mathrm{AH}$ is reduced in the presence of phosphate buffer suggesting that ligand exchange underlies the adsorption to $\mathrm{AH}$ (Aebig et al., 2007). Adsorption of CpG ODN is important for the enhancement of the immune response and excess non-adsorbed CpG ODN appears to inhibit the immune response (Mullen et al., 2007).

Muramyl dipeptide (MDP), a component of the mycobacterial cell wall, activates the innate immune system via NOD2, a cytoplasmic pattern recognition receptor. The combination of $\mathrm{AH}$ 


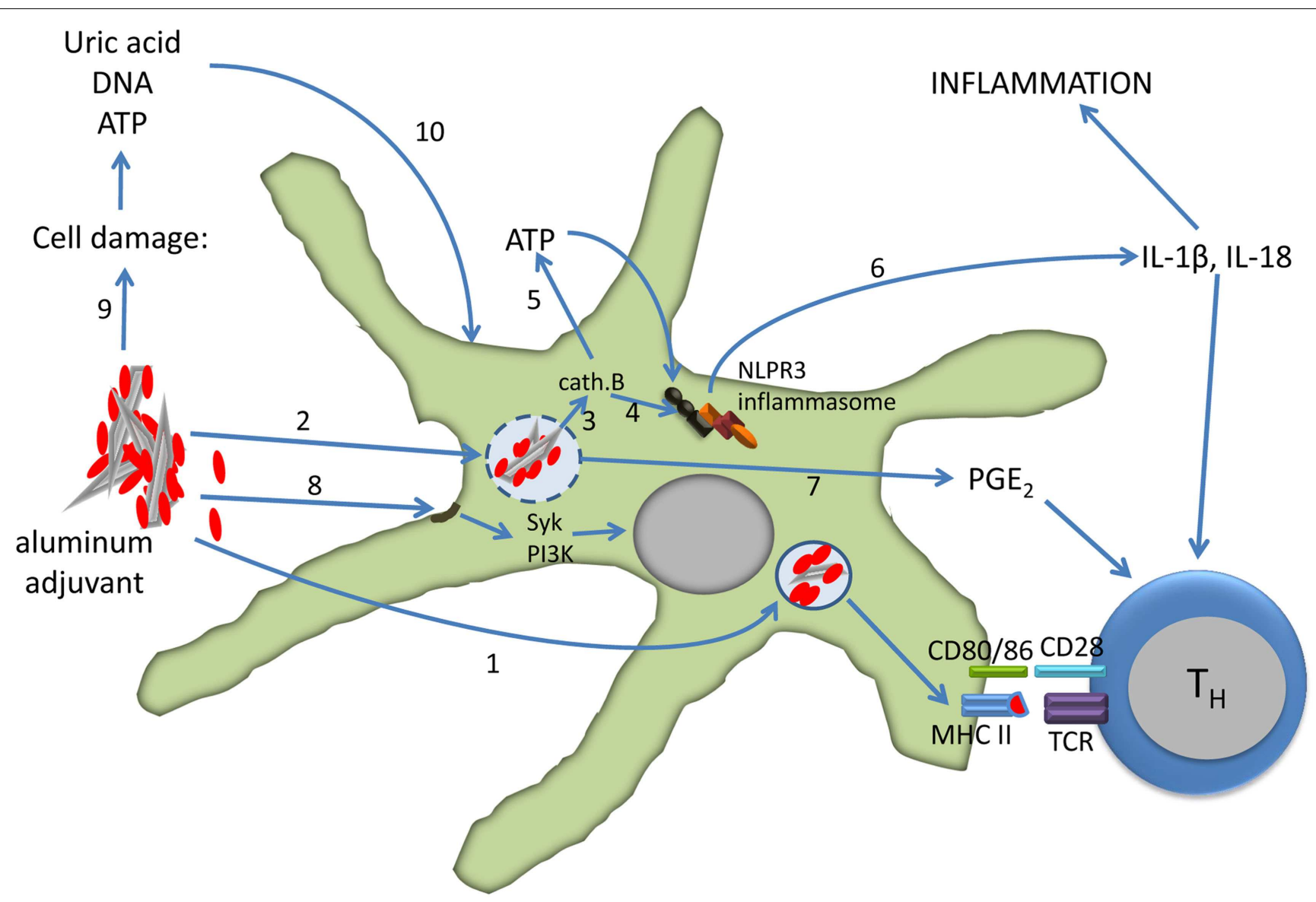

FIGURE 2 | Effect of aluminum adjuvants on dendritic cells. The particulate nature of adsorbed protein (red) antigens facilitates phagocytosis and antigen presentation (1). Uptake of aluminum adjuvants may lead to destabilization and rupture of the phagolysosome (2) which results in activation of cathepsin B (3). Cathepsin B induces the assembly of the NLPR3 inflammasome directly (4) or via extracellular release of ATP through connexin and pannexin channels (5). Caspase-1, a component of the inflammasome, cleaves pro-IL-1 $\beta$ and IL-18 into active forms that are released from the cell (6). Phagolysosome destabilization also induces the secretion of PGE2 (7), and PGE2, IL-1 $\beta$, and IL-18 all support the differentiation of CD4T cells into Th2 cells. Aluminum adjuvants also directly interact with the lipid rafts in the cell membrane which results in activation of the Syk and PI3-kinase signaling pathways (8). Injection of aluminum-adjuvanted vaccines causes cell damage and necrosis with release of uric acid, ATP, and DNA (9). These molecules in turn activate dendritic cells (10). See the text for more details and references. with MDP as adjuvant did not enhance the antibody response to a bacterial antigen in comparison with $\mathrm{AH}$ alone, but it stimulated a stronger IFN- $\gamma$ response (Moschos et al., 2006). Quil A, a partially purified mixture of saponins from the Quillaja saponaria tree, activates NALP3 inflammasomes in dendritic cells similar to aluminum adjuvants (Li et al., 2008). In spite of the overlapping mechanism of dendritic cell activation, the combination of $\mathrm{AH}$ and Quil A enhanced the antibody response and CTL response to protein antigens in comparison with $\mathrm{AH}$ alone (Wu et al., 1992; Lofthouse et al., 1995). However, Quil A failed to enhance the immune response to a bacterial antigen when combined with $\mathrm{AH}$ in another study (Moschos et al., 2006).

\section{SAFETY OF ALUMINUM-CONTAINING ADJUVANTS}

Aluminum-containing adjuvants have been used for more than 70 years in billions of doses of vaccines, and have an excellent safety record (Butler et al., 1969; Edelman, 1980; Jefferson et al., 2004). The maximum amount of aluminum adjuvant allowed in human vaccines in the US is $0.85 \mathrm{mg} \mathrm{Al} / \mathrm{dose}$, and the amount in licensed vaccines ranges from 0.125 to $0.85 \mathrm{mg} \mathrm{Al} /$ dose (Baylor et al., 2002). Aluminum is an abundant metal in the environment and is daily ingested in food and water (Willhite et al., 2012). Aluminum is also commonly used in antacids and antiperspirants. However, only small amounts of aluminum are absorbed via the intestinal barrier and the skin. Most of the aluminum is excreted via the kidneys. Aluminum toxicity from occupational exposure, renal disease, and parenteral nutrition is associated with neurologic disease and bone disease (Willhite et al., 2012). The pharmacokinetics of aluminum following intramuscular injection of $\mathrm{AH}$ and $\mathrm{AP}$ ( $0.85 \mathrm{mg} /$ dose $)$ was studied in rabbits using the rare ${ }^{26} \mathrm{Al}$ isotope as a tracer (Flarend et al., 1997). The data indicated that $17 \%$ of $\mathrm{AH}$ and $51 \%$ of AP was released into the blood circulation over a 28 day period. Based on these and other data, it was recently estimated that the concentration of aluminum in blood derived from vaccines administered to infants during the first year of life remains well below the minimum risk level established by the 
Agency for Toxic Substances and Disease Registry (Mitkus et al., 2011).

As discussed above, injection of aluminum adjuvants induces a local inflammatory reaction, and this can be associated with clinical experiences of pain, swelling, and redness at the injection site. These localized reactions are usually mild and of short duration. In fact, aluminum adjuvants reduce the prevalence and severity of systemic adverse reactions by binding and slowly releasing molecules thereby reducing toxicity. This has been demonstrated for LPS which bind tightly to AH via ligand exchange involving the two terminal phosphate groups neutralizing the activity (Norimatsu et al., 1995; Shi et al., 2001b). The prevalence of systemic adverse effects was greater in children immunized with plain DTP vaccine than in those receiving DTP with AH (Butler et al., 1969). In allergen immunotherapy, subcutaneous injection of $\mathrm{AH}$-adsorbed allergen induced fewer local reactions than the allergen in solution (Rueff et al., 2004).

The prevalence and severity of local inflammatory reactions is affected by the site of injection. Local reactions were greater following subcutaneous than intramuscular immunization of aluminum-adjuvanted DT and anthrax vaccines (Mark et al., 1999; Pittman et al., 2002). This can be attributed in part to the superficial location of subcutaneous reactions, but can also be the result of physiological differences between the tissues. Casein tightly adsorbed to $\mathrm{AH}$ persisted at the injection site longer following subcutaneous than intramuscular injection possibly reflecting differences in lymph flow rate between the subcutis and skeletal muscle (Noe et al., 2010). Contact hypersensitivity to aluminum is rare, but it has been reported following vaccination with aluminum-adjuvanted vaccines, hyposensitization with aluminum-adjuvanted allergens and the use of aluminumcontaining antiperspirants (Bergfors et al., 2003; Netterlid et al., 2009; Garg et al., 2010). It manifests itself by persistent itching nodules and contact dermatitis to antiperspirants. The contact hypersensitivity response can contribute to the inflammatory reaction at the injection site.

A muscle disease termed macrophage myofasciitis characterized by muscle weakness, myalgia, and fever was attributed to vaccination with aluminum-adjuvanted vaccines (Gherardi et al., 1998). Biopsies of the deltoid muscle demonstrated accumulation of macrophages with intracellular accumulation of aluminum hydroxide. The patients had received vaccinations 3 months to several years prior to the biopsy. The light microscopic lesions are similar to those described at the injection site in people and experimental animals injected intramuscularly with aluminum

\section{REFERENCES}

Adachi, O., Kawai, T., Takeda, K., Matsumoto, M., Tsutsui, H., Sakagami, M., et al. (1998). Targeted disruption of the MyD88 gene results in loss of IL-1- and IL18-mediated function. Immunity 9 , 143-150.

Aebig, J. A., Mullen, G. E., Dobrescu, G., Rausch, K., Lambert, L., AjosePopoola, O., et al. (2007). Formulation of vaccines containing
CpG oligonucleotides and alum. J. Immunol. Methods 323, 139-146.

Ahrens, S., Zelenay, S., Sancho, D., Hanc, P., Kjaer, S., Feest, C., et al. (2012). F-actin is an evolutionarily conserved damage-associated molecular pattern recognized by DNGR-1, a receptor for dead cells. Immunity 36 , 635-645.

Aimanianda, V., Haensler, J., LacroixDesmazes, S., Kaveri, S. V., and Bayry, J. (2009). Novel cellular and

adjuvants (Mrak, 1982; Verdier et al., 2005; Lach and Cupler, 2008). Such lesions have been demonstrated in non-human primates 12 months after injection (Verdier et al., 2005). There is no evidence that these localized injection site reactions are related to systemic muscle disease (Lach and Cupler, 2008).

In veterinary medicine, an increased prevalence of sarcomas in cats was reported in the early 1990s (Hendrick et al., 1992). The location, histologic features, and biological behavior suggested a distinct type of tumor associated with the site of vaccination (Hendrick et al., 1994; Doddy et al., 1996). The prevalence is estimated at about 1:3,000-1:10,000 vaccinations. Aluminum was identified in some of the sarcomas that were present at sites of previous vaccination in cats (Hendrick et al., 1992). This suggested a possible causal role of aluminum adjuvants in the development of sarcomas, but subsequent epidemiologic studies failed to demonstrate an association between particular types of vaccines and sarcomas (Kass et al., 2003). However, a recent report indicated that cats with sarcomas in the rear lower limb were less likely to have received recombinant rabies vaccine without adjuvant than an adjuvanted inactivated rabies vaccine (Srivastav et al., 2012). Non-adjuvanted vaccines induced less severe inflammation than adjuvanted vaccines at the subcutaneous injection site in cats (Day et al., 2007). Sarcomas have also been reported in cats in association with injections other than vaccines including long acting penicillin and corticosteroid medications (Kass et al., 2003; Srivastav et al., 2012). This suggests that there is a small subpopulation of cats that is prone to develop sarcomas at sites of chronic inflammation, and no specific role for aluminum adjuvant in the pathogenesis of these neoplasms. There is no evidence of sarcomas caused by injection of aluminum-adjuvanted vaccines or allergens in people (Jekel et al., 1978).

\section{CONCLUSION}

Aluminum-containing adjuvants are widely used in preventive vaccines against infectious diseases and in immunotherapy of allergies. Recent studies have begun to increase our understanding of the mechanisms involved in adsorption of antigens onto aluminum adjuvants and the effect of adsorption on the stability of antigens and the immune response. Aluminum adjuvants appear to enhance the immune response via several molecular pathways, but more work is needed to understand the interactions and relative importance of these pathways. This knowledge will help to determine the optimal formulation conditions for effective and safe aluminum-adjuvanted vaccines.

molecular mechanisms of induction of immune responses by aluminum adjuvants. Trends Pharmacol. Sci.30, 287-295.

Ausar, S. F., Chan, J., Hoque, W., James, O., Jayasundara, K., and Harper, K. (2011). Application of extrinsic fluorescence spectroscopy for the high throughput formulation screening of aluminum-adjuvanted vaccines. J. Pharm. Sci. 100, 431-440.
Baylor, N. W., Egan, W., and Richman, P. (2002). Aluminum salts in vaccines US perspective. Vaccine 20(Suppl. 3), S18-S23.

Bergfors, E., Trollfors, B., and Inerot, A. (2003). Unexpectedly high incidence of persistent itching nodules and delayed hypersensitivity to aluminium in children after the use of adsorbed vaccines from a single manufacturer. Vaccine 22, 64-69. 
Berthold, I., Pombo, M. L., Wagner, L., and Arciniega, J. L. (2005). Immunogenicity in mice of anthrax recombinant protective antigen in the presence of aluminum adjuvants. Vaccine 23, 1993-1999.

Brewer, J. M., Conacher, M., Satoskar, A., Bluethmann, H., and Alexander, J. (1996). In interleukin-4-deficient mice, alum not only generates $\mathrm{T}$ helper 1 responses equivalent to freund's complete adjuvant, but continues to induce $\mathrm{T}$ helper 2 cytokine production. Eur. J. Immunol. 26, 2062-2066.

Burrell, L. S., Johnston, C. T., Schulze, D., Klein, J., White, J. L., and Hem, S. L. (2000a). Aluminium phosphate adjuvants prepared by precipitation at constant pH. Part I: composition and structure. Vaccine 19, 275-281.

Burrell, L. S., Johnston, C. T., Schulze, D., Klein, J., White, J. L., and Hem, S. L. (2000b). Aluminium phosphate adjuvants prepared by precipitation at constant pH. Part II: physicochemical properties. Vaccine 19, 282-287.

Butler, N. R., Voyce, M. A., Burland, W. L., and Hilton, M. L. (1969). Advantages of aluminium hydroxide adsorbed combined diphtheria, tetanus, and pertussis vaccines for the immunization of infants. $\mathrm{Br}$. Med. J. 1, 663-666.

Calabro, S., Tortoli, M., Baudner, B. C., Pacitto, A., Cortese, M., O'Hagan, D. T., et al. (2011). Vaccine adjuvants alum and MF59 induce rapid recruitment of neutrophils and monocytes that participate in antigen transport to draining lymph nodes. Vaccine 29, 1812-1823.

Chang, M., Shi, Y., Nail, S. L., HogenEsch, H., Adams, S. B., White, J. L., et al. (2001). Degree of antigen adsorption in the vaccine or interstitial fluid and its effect on the antibody response in rabbits. Vaccine 19 , 2884-2889.

Clapp, T., Siebert, P., Chen, D., and Jones Braun, L. (2011). Vaccines with aluminum-containing adjuvants: optimizing vaccine efficacy and thermal stability. J. Pharm. Sci. $100,388-401$.

Coffman, R. L., Sher, A., and Seder, R. A. (2010). Vaccine adjuvants: putting innate immunity to work. Immunity 33, 492-503.

Comoy, E. E., Capron, A., and Thyphronitis, G. (1997). In vivo induction of type 1 and 2 immune responses against protein antigens. Int. Immunol. 9, 523-531.

Compeer, E. B., Flinsenberg, T. W., Van Der Grein, S. G., and Boes, M. (2012). Antigen processing and remodeling of the endosomal pathway: requirements for antigen crosspresentation. Front. Immunol. 3:37. doi:10.3389/fimmu.2012.00037

Conforti-Andreoni, C., Spreafico, R., Qian, H. L., Riteau, N., Ryffel, B., Ricciardi-Castagnoli, P., et al. (2011). Uric acid-driven Th17 differentiation requires inflammasome-derived IL-1 and IL-18. J. Immunol. 187, 5842-5850.

Cooper, C. L., Davis, H. L., Morris, M. L., Efler, S. M., Adhami, M. A., Krieg, A. M., et al. (2004). CPG 7909, an immunostimulatory TLR9 agonist oligodeoxynucleotide, as adjuvant to Engerix-B HBV vaccine in healthy adults: a double-blind phase I/II study. J. Clin. Immunol. 24, 693-701. Cruz, C. M., Rinna, A., Forman, H. J., Ventura, A. L., Persechini, P. M., and Ojcius, D. M. (2007). ATP activates a reactive oxygen species-dependent oxidative stress response and secretion of proinflammatory cytokines in macrophages. J. Biol. Chem. 282, 2871-2879.

Cunningham, A. F., Serre, K., Toellner, K. M., Khan, M., Alexander, J., Brombacher, F., et al. (2004). Pinpointing IL-4-independent acquisition and IL-4-influenced maintenance of Th2 activity by CD $4 \mathrm{~T}$ cells. Eur. J. Immunol. 34, 686-694.

Curtsinger, J. M., Lins, D. C., and Mescher, M. F. (2003). Signal 3 determines tolerance versus full activation of naive $\mathrm{CD} 8 \mathrm{~T}$ cells: dissociating proliferation and development of effector function. J. Exp. Med. 197, 1141-1151.

Dagouassat, N., Robillard, V., Haeuw, J. F., Plotnicky-Gilquin, H., Power, U. F., Corvaia, N., et al. (2001). A novel bipolar mode of attachment to aluminium-containing adjuvants by BBG2Na, a recombinant subunit hRSV vaccine. Vaccine 19, 4143-4152.

Davis, H. L., Weeratna, R., Waldschmidt, T. J., Tygrett, L., Schorr, J., and Krieg, A. M. (1998). CpG DNA is a potent enhancer of specific immunity in mice immunized with recombinant hepatitis B surface antigen. $J$. Immunol. 160, 870-876.

Day, M. J., Schoon, H. A., Magnol, J. P., Saik, J., Devauchelle, P., Truyen, U., et al. (2007). A kinetic study of histopathological changes in the subcutis of cats injected with nonadjuvanted and adjuvanted multicomponent vaccines. Vaccine 25, 4073-4084.

de Veer, M., Kemp, J., Chatelier, J., Elhay, M. J., and Meeusen, E. N. (2010). The kinetics of soluble and particulate antigen trafficking in the afferent lymph, and its modulation by aluminum-based adjuvant. Vaccine 28, 6597-6602.

Didierlaurent, A. M., Morel, S., Lockman, L., Giannini, S. L., Bisteau, M. Carlsen, H., et al. (2009). AS04, an aluminum salt- and TLR4 agonistbased adjuvant system, induces a transient localized innate immune response leading to enhanced adaptive immunity. J. Immunol. 183 6186-6197.

Dillon, S. B., Demuth, S. G., Schneider, M. A., Weston, C. B., Jones, C. S., Young, J. F., et al. (1992). Induction of protective class I MHCrestricted CTL in mice by a recombinant influenza vaccine in aluminium hydroxide adjuvant. Vaccine 10, 309-318.

Doddy, F. D., Glickman, L. T., Glickman, N. W., and Janovitz, E. B. (1996). Feline fibrosarcomas at vaccination sites and non-vaccination sites. $J$. Comp. Pathol. 114, 165-174.

Edelman, R. (1980). Vaccine adjuvants. Rev. Infect. Dis. 2, 370-383.

Eifan, A. O., Shamji, M. H., and Durham, S. R. (2011). Long-term clinical and immunological effects of allergen immunotherapy. Curr. Opin. Allergy Clin. Immunol. 11, 586-593.

Eisenbarth, S. C., Colegio, O. R., O'Connor, W., Sutterwala, F. S., and Flavell, R. A. (2008). Crucial role for the Nalp3 inflammasome in the immunostimulatory properties of aluminium adjuvants. Nature 453 1122-1126.

Estey, T., Vessely, C., Randolph, T. W., Henderson, I., Braun, L. J., Nayar, R. et al. (2009). Evaluation of chemical degradation of a trivalent recombinant protein vaccine against botulinum neurotoxin by LysC peptide mapping and MALDI-TOF mass spectrometry. J. Pharm. Sci. 98, 2994-3012.

Exley, C., Siesjo, P., and Eriksson, H. (2010). The immunobiology of aluminium adjuvants: how do they really work? Trends Immunol. 31, 103-109.

Flach, T. L., Ng, G., Hari, A., Desrosiers, M. D., Zhang, P., Ward, S. M., et al. (2011). Alum interaction with dendritic cell membrane lipids is essential for its adjuvanticity. Nat. Med. $17,479-487$.

Flarend, R. E., Hem, S. L., White, J. L., Elmore, D., Suckow, M. A., Rudy, A. C., et al. (1997). In vivo absorption of aluminium-containing vaccine adjuvants using 26Al. Vaccine $15,1314-1318$.

Franchi, L., and Nunez, G. (2008). The Nlrp3 inflammasome is critical for aluminium hydroxide-mediated IL1beta secretion but dispensable for adjuvant activity. Eur. J. Immunol. 38, 2085-2089.

Francis, J. N., and Durham, S. R. (2004). Adjuvants for allergen immunotherapy: experimental results and clinical perspectives. Curr. Opin. Allergy Clin. Immunol. 4, 543-548.

Frazer, I. H., Leggatt, G. R., and Mattarollo, S. R. (2011). Prevention and treatment of papillomavirusrelated cancers through immunization. Annu. Rev. Immunol. 29, 111-138.

Garcon, N. (2010). Preclinical development of AS04. Methods Mol. Biol. $626,15-27$

Garg, S., Loghdey, S., and Gawkrodger, D. J. (2010). Allergic contact dermatitis from aluminium in deodorants. Contact Derm. 62, 57-58.

Garulli, B., Stillitano, M. G., Barnaba, V., and Castrucci, M. R. (2008). Primary CD8+ T-cell response to soluble ovalbumin is improved by chloroquine treatment in vivo. Clin. Vaccine Immunol. 15, 1497-1504.

Gavin, A. L., Hoebe, K., Duong, B., Ota, T., Martin, C., Beutler, B., et al. (2006). Adjuvant-enhanced antibody responses in the absence of tolllike receptor signaling. Science 314, 1936-1938.

Gherardi, R. K., Coquet, M., Cherin, P., Authier, F. J., Laforet, P., Belec L., et al. (1998). Macrophagic myofasciitis: an emerging entity. Groupe d'Etudes et Recherche sur les Maladies Musculaires Acquises et Dysimmunitaires (GERMMAD) de l'Association Francaise contre les Myopathies (AFM). Lancet 352, 347-352.

Ghimire, T. R., Benson, R. A., Garside, P., and Brewer, J. M. (2012). Alum increases antigen uptake, reduces antigen degradation and sustains antigen presentation by DCs in vitro. Immunol. Lett. 147, 55-62.

Giannini, S. L., Hanon, E., Moris, P. Van Mechelen, M., Morel, S., Dessy, F., et al. (2006). Enhanced humoral and memory B cellular immunity using HPV16/18 L1 VLP vaccine formulated with the MPL/aluminium salt combination (AS04) compared to aluminium salt only. Vaccine 24 , 5937-5949.

Glenny, A. T., Pope, C. G., Waddington, H., and Wallace, U. (1926). Immunological notes. XVI1-XXIV. J. Pathol. Bacteriol. 29, 31-40.

Goto, N., and Akama, K. (1982). Histopathological studies of reactions in mice injected with aluminum-adsorbed tetanus toxoid. Microbiol. Immunol. 26, 1121-1132. 
Goto, N., Kato, H., Maeyama, J., Shibano, M., Saito, T., Yamaguchi, J., et al. (1997). Local tissue irritating effects and adjuvant activities of calcium phosphate and aluminium hydroxide with different physical properties. Vaccine 15, 1364-1371.

Gupta, R. K. (1998). Aluminum compounds as vaccine adjuvants. $A d v$. Drug Deliv. Rev. 32, 155-172.

Guy, B. (2007). The perfect mix: recent progress in adjuvant research. Nat. Rev. Microbiol. 5, 505-517.

Hammad, H., Plantinga, M., Deswarte, K., Pouliot, P., Willart, M. A., Kool, M., et al. (2010). Inflammatory dendritic cells - not basophils - are necessary and sufficient for induction of Th2 immunity to inhaled house dust mite allergen. J. Exp. Med. 207, 2097-2111.

Hansen, B., Belfast, M., Soung, G., Song, L., Egan, P. M., Capen, R., et al. (2009). Effect of the strength of adsorption of hepatitis B surface antigen to aluminum hydroxide adjuvant on the immune response. Vaccine 27, 888-892.

Hansen, B., Sokolovska, A., HogenEsch, H., and Hem, S. L. (2007). Relationship between the strength of antigen adsorption to an aluminum-containing adjuvant and the immune response. Vaccine 25, 6618-6624.

Hem, S. L., and HogenEsch, H. (2007). Relationship between physical and chemical properties of aluminum-containing adjuvants and immunopotentiation. Expert Rev. Vaccines 6, 685-698.

Hem, S. L., Johnston, C. T., and HogenEsch, H. (2007). Imject alum is not aluminum hydroxide adjuvant or aluminum phosphate adjuvant. Vaccine 25, 4985-4986.

Hendrick, M. J., Goldschmidt, M. H., Shofer, F. S., Wang, Y. Y., and Somlyo, A. P. (1992). Postvaccinal sarcomas in the cat: epidemiology and electron probe microanalytical identification of aluminum. Cancer Res. 52, 5391-5394.

Hendrick, M. J., Shofer, F. S., Goldschmidt, M. H., Haviland, J. C., Schelling, S. H., Engler, S. J., et al. (1994). Comparison of fibrosarcomas that developed at vaccination sites and at nonvaccination sites in cats: 239 cases (1991-1992). J. Am. Vet. Med. Assoc. 205, 1425-1429.

Hjorth, M., Axelsson, S., Ryden, A., Faresjo, M., Ludvigsson, J., and Casas, R. (2011). GAD-alum treatment induces GAD65-specific CD4+ CD25highFOXP3 + cells in type 1 diabetic patients. Clin. Immunol. 138, 117-126.
HogenEsch, H., Dunham, A., Hansen, B., Anderson, K., Maisonneuve, J. F., and Hem, S. L. (2011). Formulation of a killed whole cell pneumococcus vaccine - effect of aluminum adjuvants on the antibody and IL17 response. J. Immune Based Ther. Vaccines 9, 5.

Holt, L. B. (1950). Developments in Diphtheria Prophylaxis. London: W. Heinemann, Ltd.

Hornung, V., Bauernfeind, F., Halle, A., Samstad, E. O., Kono, H., Rock, K. L., et al. (2008). Silica crystals and aluminum salts activate the NALP3 inflammasome through phagosomal destabilization. Nat. Immunol. 9, 847-856.

Hutchison, S., Benson, R. A., Gibson, V. B., Pollock, A. H., Garside, P., and Brewer, J. M. (2012). Antigen depot is not required for alum adjuvanticity. FASEB J. 26, 1272-1279.

Iyer, S., HogenEsch, H., and Hem, S. L. (2003). Relationship between the degree of antigen adsorption to aluminum hydroxide adjuvant in interstitial fluid and antibody production. Vaccine 21, 1219-1223.

Iyer, V., Hu, L., Liyanage, M. R., Esfandiary, R., Reinisch, C., Meinke, A., et al. (2012). Preformulation characterization of an aluminum salt-adjuvanted trivalent recombinant protein-based vaccine candidate against streptococcus pneumoniae. J. Pharm. Sci. 101, 3078-3090.

Jefferson, T., Rudin, M., and Di Pietrantonj, C. (2004). Adverse events after immunisation with aluminium-containing DTP vaccines: systematic review of the evidence. Lancet Infect. Dis. 4, 84-90.

Jekel, J. F., Freeman, D. H., and Meigs, J. W. (1978). A study of trends in upper arm soft tissue sarcomas in the state of connecticut following the introduction of alum-absorbed allergenic extract. Ann. Allergy 40, 28-31.

Joffre, O. P., Segura, E., Savina, A., and Amigorena, S. (2012). Crosspresentation by dendritic cells. Nat. Rev. Immunol. 12, 557-569.

Johnston, C. T., Wang, S. L., and Hem, S. L. (2002). Measuring the surface area of aluminum hydroxide adjuvant. $J$. Pharm. Sci. 91, 1702-1706.

Johnston, R. J., Poholek, A. C., Ditoro, D., Yusuf, I., Eto, D., Barnett, B., et al. (2009). Bcl6 and Blimp-1 are reciprocal and antagonistic regulators of $\mathrm{T}$ follicular helper cell differentiation. Science 325, 1006-1010.

Jones, F. G. M. J. M. (1936). Studies on tetanus toxoid: I. The antitoxic titer of human subjects following immunization with tetanus toxoid and tetanus alum precipitated toxoid. $J$. Immunol. 30, 115-125.

Jones, L. S., Peek, L. J., Power, J. Markham, A., Yazzie, B., and Middaugh, C. R. (2005). Effects of adsorption to aluminum salt adjuvants on the structure and stability of model protein antigens. J. Biol. Chem. 280, 13406-13414.

Jordan, M. B., Mills, D. M., Kappler, J., Marrack, P., and Cambier, J. C. (2004). Promotion of B cell immune responses via an aluminduced myeloid cell population. Science 304, 1808-1810.

Joshi, A., Bauer, R., Kuebler, P., White, M., Leddy, C., Compton, P., et al. (2006). An overview of the pharmacokinetics and pharmacodynamics of efalizumab: a monoclonal antibody approved for use in psoriasis. J. Clin. Pharmacol. 46, 10-20.

Kass, P. H., Spangler, W. L., Hendrick, M. J., McGill, L. D., Esplin, D. G., Lester, S., et al. (2003). Multicenter case-control study of risk factors associated with development of vaccine-associated sarcomas in cats. J. Am. Vet. Med. Assoc. 223, 1283-1292.

Kool, M., Fierens, K., and Lambrecht, B. N. (2012). Alum adjuvant: some of the tricks of the oldest adjuvant. $J$. Med. Microbiol. 61, 927-934.

Kool, M., Petrilli, V., De Smedt, T. Rolaz, A., Hammad, H., Van Nimwegen, M., et al. (2008a). Cutting edge: alum adjuvant stimulates inflammatory dendritic cells through activation of the NALP3 inflammasome. J. Immunol. 181, 3755-3759.

Kool, M., Soullie, T., Van Nimwegen, M., Willart, M. A., Muskens, F., Jung, S., et al. (2008b). Alum adjuvant boosts adaptive immunity by inducing uric acid and activating inflammatory dendritic cells. J. Exp. Med. 205, 869-882.

Kool, M., Willart, M. A., Van Nimwegen, M., Bergen, I., Pouliot, P., Virchow, J. C., et al. (2011). An unexpected role for uric acid as an inducer of $\mathrm{T}$ helper 2 cell immunity to inhaled antigens and inflammatory mediator of allergic asthma. Immunity 34, 527-540.

Korsholm, K. S., Petersen, R. V., Agger, E. M., and Andersen, P. (2010). Thelper 1 and T-helper 2 adjuvants induce distinct differences in the magnitude, quality and kinetics of the early inflammatory response at the site of injection. Immunology 129, 75-86.

Kuroda, E., Ishii, K. J., Uematsu, S., Ohata, K., Coban, C., Akira, S., et al. (2011). Silica crystals and aluminum salts regulate the production of prostaglandin in macrophages via NALP3 inflammasome-independent mechanisms. Immunity 34, 514-526.

Kwissa, M., Lindblad, E. B., Schirmbeck, R., and Reimann, J. (2003). Codelivery of a DNA vaccine and a protein vaccine with aluminum phosphate stimulates a potent and multivalent immune response. J. Mol. Med. (Berl.) 81, 502-510.

Lach, B., and Cupler, E. J. (2008). Macrophagic myofasciitis in children is a localized reaction to vaccination. J. Child Neurol. 23, 614-619.

Lee, M., Jantaratnotai, N., McGeer, E., McLarnon, J. G., and McGeer, P. L. (2011). $\mathrm{Mg} 2+$ ions reduce microglial and THP-1 cell neurotoxicity by inhibiting $\mathrm{Ca} 2+$ entry through purinergic channels. Brain Res. 1369, 21-35.

Leeling, J. L., Muni, I. A., Helms, R. J., and Johnson, N. Jr. (1979). Rates of release of subcutaneously injected antigens in the rat. Comparison of an aqueous preparation with two alum-precipitated preparations. Allergy 34, 339-344.

Lefeber, D. J., Benaissa-Trouw, B., Vliegenthart, J. F., Kamerling, J. P., Jansen, W. T., Kraaijeveld, K., et al. (2003). Th1-directing adjuvants increase the immunogenicity of oligosaccharide-protein conjugate vaccines related to Streptococcus pneumoniae type 3. Infect. Immun. 71, 6915-6920.

Li, H., Nookala, S., and Re, F. (2007). Aluminum hydroxide adjuvants activate caspase- 1 and induce IL-1beta and IL-18 release. J. Immunol. 178, 5271-5276.

Li, H., Willingham, S. B., Ting, J. P., and Re, F. (2008). Cutting edge: inflammasome activation by alum and alum's adjuvant effect are mediated by NLRP3. J. Immunol. 181, 17-21.

Lin, L., Ibrahim, A. S., Xu, X., Farber, J. M., Avanesian, V., Baquir, B., et al. (2009). Th1-Th17 cells mediate protective adaptive immunity against Staphylococcus aureus and Candida albicans infection in mice. PLoS Pathog. 5:e1000703. doi:10.1371/journal.ppat.1000703

Lindblad, E. B. (2004). Aluminium compounds for use in vaccines. Immunol. Cell Biol. 82, 497-505.

Ljutic, B., Ochs, M., Messham, B., Ming, M., Dookie, A., Harper, K., et al. (2012). Formulation, stability and immunogenicity of a trivalent pneumococcal protein vaccine formulated with aluminum salt adjuvants. Vaccine 30, 2981-2988. 
Lofthouse, S. A., Andrews, A. E., Nash, A. D., and Bowles, V. M. (1995). Humoral and cellular responses induced by intradermally administered cytokine and conventional adjuvants. Vaccine 13, 1131-1137.

Lu, Y. J., Gross, J., Bogaert, D., Finn, A., Bagrade, L., Zhang, Q., et al. (2008). Interleukin-17A mediates acquired immunity to pneumococcal colonization. PLoS Pathog. 4:e1000159. doi:10.1371/journal.ppat.1000159

Ludvigsson, J., Faresjo, M., Hjorth, M., Axelsson, S., Cheramy, M., Pihl, M., et al. (2008). GAD treatment and insulin secretion in recent-onset type 1 diabetes. N. Engl. J. Med. 359, 1909-1920.

Mach, H., Gregory, S. M., Mackiewicz, A., Mittal, S., Lalloo, A., Kirchmeier, M., et al. (2011). Electrostatic interactions of monoclonal antibodies with subcutaneous tissue. Ther. Deliv. 2, 727-736.

MacLeod, M. K., McKee, A. S., David, A., Wang, J., Mason, R., Kappler, J. W., et al. (2011). Vaccine adjuvants aluminum and monophosphoryl lipid A provide distinct signals to generate protective cytotoxic memory CD8 $\mathrm{T}$ cells. Proc. Natl. Acad. Sci. U.S.A. 108, 7914-7919.

Mannhalter, J. W., Neychev, H. O., Zlabinger, G. J., Ahmad, R., and Eibl, M. M. (1985). Modulation of the human immune response by the non-toxic and non-pyrogenic adjuvant aluminium hydroxide: effect on antigen uptake and antigen presentation. Clin. Exp. Immunol. 61, 143-151.

Manning, M. C., Chou, D. K., Murphy, B. M., Payne, R. W., and Katayama, D. S. (2010). Stability of protein pharmaceuticals: an update. Pharm. Res. 27, 544-575.

Marichal, T., Ohata, K., Bedoret, D., Mesnil, C., Sabatel, C., Kobiyama, K., et al. (2011). DNA released from dying host cells mediates aluminum adjuvant activity. Nat. Med. 17, 996-1002.

Mark, A., Carlsson, R. M., and Granstrom, M. (1999). Subcutaneous versus intramuscular injection for booster DT vaccination of adolescents. Vaccine 17, 2067-2072.

Marrack, P., McKee, A. S., and Munks, M. W. (2009). Towards an understanding of the adjuvant action of aluminium. Nat. Rev. Immunol. 9, 287-293.

Martinon, F., Mayor, A., and Tschopp, J. (2009). The inflammasomes: guardians of the body. Annu. Rev. Immunol. 27, 229-265.

McKee, A. S., MacLeod, M., White, J., Crawford, F., Kappler, J. W., and Marrack, P. (2008). Gr1+IL-4producing innate cells are induced in response to Th2 stimuli and suppress Th1-dependent antibody responses. Int. Immunol. 20, 659-669.

McKee, A. S., Munks, M. W., MacLeod, M. K., Fleenor, C. J., Van Rooijen, N., Kappler, J. W., et al. (2009). Alum induces innate immune responses through macrophage and mast cell sensors, but these sensors are not required for alum to act as an adjuvant for specific immunity. $J$. Immunol. 183, 4403-4414.

Mitkus, R. J., King, D. B., Hess, M. A., Forshee, R. A., and Walderhaug, M. O. (2011). Updated aluminum pharmacokinetics following infant exposures through diet and vaccination. Vaccine 29, 9538-9543.

Morefield, G. L., Sokolovska, A., Jiang, D., HogenEsch, H., Robinson, J. P., and Hem, S. L. (2005). Role of aluminum-containing adjuvants in antigen internalization by dendritic cells in vitro. Vaccine 23, 1588-1595.

Morefield, G. L., Tammariello, R. F., Purcell, B. K., Worsham, P. L., Chapman, J., Smith, L. A., et al. (2008). An alternative approach to combination vaccines: intradermal administration of isolated components for control of anthrax, botulism, plague and staphylococcal toxic shock. J. Immune Based Ther. Vaccines 6, 5.

Mori, A., Oleszycka, E., Sharp, F. A., Coleman, M., Ozasa, Y., Singh, M., et al. (2012). The vaccine adjuvant alum inhibits IL-12 by promoting PI3 kinase signaling while chitosan does not inhibit IL-12 and enhances Th1 and Th17 responses. Eur. J. Immunol. 42, 2709-2719.

Mosca, F., Tritto, E., Muzzi, A., Monaci, E., Bagnoli, F., Iavarone, C., et al. (2008). Molecular and cellular signatures of human vaccine adjuvants. Proc. Natl. Acad. Sci. U.S.A. 105, 10501-10506.

Moschos, S. A., Bramwell, V. W., Somavarapu, S., and Alpar, H. O. (2006). Modulating the adjuvanticity of alum by co-administration of muramyl di-peptide (MDP) or Quil-A. Vaccine 24, 1081-1086.

Mosmann, T. R., Cherwinski, H., Bond, M. W., Giedlin, M. A., and Coffman, R. L. (1986). Two types of murine helper $\mathrm{T}$ cell clone. I. Definition according to profiles of lymphokine activities and secreted proteins. $J$. Immunol. 136, 2348-2357.

Mrak, R. E. (1982). Muscle granulomas following intramuscular injection. Muscle Nerve 5, 637-639.

Mullen, G. E., Aebig, J. A., Dobrescu, G., Rausch, K., Lambert, L., Long, C. A., et al. (2007). Enhanced antibody production in mice to the malaria antigen AMA1 by CPG 7909 requires physical association of $\mathrm{CpG}$ and antigen. Vaccine 25, 5343-5347.

Netterlid, E., Hindsen, M., Bjork, J., Ekqvist, S., Guner, N., Henricson, K. A., et al. (2009). There is an association between contact allergy to aluminium and persistent subcutaneous nodules in children undergoing hyposensitization therapy. Contact Derm. 60, 41-49.

Noe, S. M., Green, M. A., HogenEsch, H., and Hem, S. L. (2010). Mechanism of immunopotentiation by aluminum-containing adjuvants elucidated by the relationship between antigen retention at the inoculation site and the immune response. Vaccine 28, 3588-3594.

Norimatsu, M., Ogikubo, Y., Aoki, A., Takahashi, T., Watanabe, G., Taya, K., et al. (1995). Effects of aluminum adjuvant on systemic reactions of lipopolysaccharides in swine. $\mathrm{Vac}$ cine 13, 1325-1329.

Nurieva, R. I., Chung, Y., Martinez, G. J., Yang, X. O., Tanaka, S., Matskevitch, T. D., et al. (2009). Bcl6 mediates the development of $\mathrm{T}$ follicular helper cells. Science 325, 1001-1005.

Ohnmacht, C., Schwartz, C., Panzer, M., Schiedewitz, I., Naumann, R., and Voehringer, D. (2010). Basophils orchestrate chronic allergic dermatitis and protective immunity against helminths. Immunity 33, 364-374.

Okoye, I. S., and Wilson, M. S. (2011). CD4+ T helper 2 cells microbial triggers, differentiation requirements and effector functions. Immunology 134, 368-377.

Pearce, E. L., and Shen, H. (2007). Generation of CD8 $\mathrm{T}$ cell memory is regulated by IL-12. J. Immunol. 179, 2074-2081.

Peek, L. J., Martin, T. T., Elk Nation, C., Pegram, S. A., and Middaugh, C. R. (2007). Effects of stabilizers on the destabilization of proteins upon adsorption to aluminum salt adjuvants. J. Pharm. Sci. 96, 547-557.

Perrigoue, J. G., Saenz, S. A., Siracusa, M. C., Allenspach, E. J., Taylor, B. C. Giacomin, P. R., et al. (2009). MHC class II-dependent basophil-CD4+ $\mathrm{T}$ cell interactions promote $\mathrm{T}(\mathrm{H}) 2$ cytokine-dependent immunity. Nat. Immunol. 10, 697-705.

Petty, R. E., and Steward, M. W. (1977) The effect of immunological adjuvants on the relative affinity of antiprotein antibodies. Immunology 32 , 49-55.

Pittman, P. R., Kim-Ahn, G., Pifat, D. Y., Coonan, K., Gibbs, P., Little, S., et al. (2002). Anthrax vaccine: immunogenicity and safety of a dose-reduction, route-change comparison study in humans. Vaccine 20, 1412-1420

Rimaniol, A. C., Gras, G., Verdier, F., Capel, F., Grigoriev, V. B., Porcheray, F., et al. (2004). Aluminum hydroxide adjuvant induces macrophage differentiation towards a specialized antigen-presenting cell type. Vaccine 22, 3127-3135.

Riteau, N., Baron, L., Villeret, B., Guillou, N., Savigny, F., Ryffel, B., et al. (2012). ATP release and purinergic signaling: a common pathway for particle-mediated inflammasome activation. Cell Death Dis. 3, e403.

Rock, K. L., Latz, E., Ontiveros, F., and Kono, H. (2010). The sterile inflammatory response. Annu. Rev. Immunol. 28, 321-342.

Romero Mendez, I. Z., Shi, Y. HogenEsch, H., and Hem, S. L. (2007). Potentiation of the immune response to non-adsorbed antigens by aluminum-containing adjuvants. Vaccine 25, 825-833.

Rueff, F., Wolf, H., Schnitker, J., Ring, J., and Przybilla, B. (2004). Specific immunotherapy in honeybee venom allergy: a comparative study using aqueous and aluminium hydroxide adsorbed preparations. Allergy 59, 589-595.

Schnare, M., Barton, G. M., Holt, A. C. Takeda, K., Akira, S., and Medzhitov, R. (2001). Toll-like receptors control activation of adaptive immune responses. Nat. Immunol. 2, 947-950.

Serre, K., Benezech, C., Desanti, G., Bobat, S., Toellner, K. M., Bird, R., et al. (2011a). Helios is associated with CD4 $\mathrm{T}$ cells differentiating to $\mathrm{T}$ helper 2 and follicular helper $\mathrm{T}$ cells in vivo independently of Foxp3 expression. PLoS ONE 6:e20731. doi:10.1371/journal.pone.0020731

Serre, K., Mohr, E., Benezech, C., Bird, R., Khan, M., Caamano, J. H., et al. (2011b). Selective effects of NFkappaB1 deficiency in CD4(+) $\mathrm{T}$ cells on Th2 and TFh induction by alum-precipitated protein vaccines. Eur. J. Immunol. 41, 1573-1582.

Serre, K., Mohr, E., Gaspal, F., Lane, P. J., Bird, R., Cunningham, A. F., et al. (2010). IL-4 directs both CD4 and CD8 $\mathrm{T}$ cells to produce Th2 cytokines in vitro, but only CD4 $\mathrm{T}$ cells produce these cytokines in response to alum-precipitated protein in vivo. Mol. Immunol. 47, 1914-1922.

Seubert, A., Monaci, E., Pizza, M. O’Hagan, D. T., and Wack, A. (2008). The adjuvants aluminum hydroxide and MF59 induce monocyte and 
granulocyte chemoattractants and enhance monocyte differentiation toward dendritic cells. J. Immunol. 180, 5402-5412.

Sharp, F. A., Ruane, D., Claass, B., Creagh, E., Harris, J., Malyala, P., et al. (2009). Uptake of particulate vaccine adjuvants by dendritic cells activates the NALP3 inflammasome. Proc. Natl. Acad. Sci. U.S.A. 106, 870-875.

Shi, Y., Evans, J. E., and Rock, K. L. (2003). Molecular identification of a danger signal that alerts the immune system to dying cells. Nature 425, 516-521.

Shi, Y., HogenEsch, H., and Hem, S. L. (2001a). Change in the degree of adsorption of proteins by aluminum-containing adjuvants following exposure to interstitial fluid: freshly prepared and aged model vaccines. Vaccine 20, 80-85.

Shi, Y., HogenEsch, H., Regnier, F. E. and Hem, S. L. (2001b). Detoxification of endotoxin by aluminum hydroxide adjuvant. Vaccine 19, 1747-1752.

Shirodkar, S., Hutchinson, R. L., Perry, D. L., White, J. L., and Hem, S. L. (1990). Aluminum compounds used as adjuvants in vaccines. Pharm. Res. 7, 1282-1288.

Soehnlein, O., and Lindbom, L. (2010). Phagocyte partnership during the onset and resolution of inflammation. Nat. Rev. Immunol. 10, 427-439.

Sokol, C. L., Chu, N. Q., Yu, S., Nish, S. A., Laufer, T. M., and Medzhitov, R. (2009). Basophils function as antigen-presenting cells for an allergen-induced $\mathrm{T}$ helper type 2 response. Nat. Immunol. 10, 713-720.

Sokolovska, A., Hem, S. L., and HogenEsch, H. (2007). Activation of dendritic cells and induction of $\mathrm{CD} 4(+) \mathrm{T}$ cell differentiation by aluminum-containing adjuvants. Vaccine 25, 4575-4585.

Soliakov, A., Kelly, I. F., Lakey, J. H., and Watkinson, A. (2012). Anthrax sub-unit vaccine: the structural consequences of binding rPA83 to Alhydrogel(R). Eur. J. Pharm. Biopharm. $80,25-32$.

Spazierer, D., Skvara, H., Dawid, M., Fallahi, N., Gruber, K., Rose, K., et al. (2009). T helper 2 biased de novo immune response to Keyhole Limpet Hemocyanin in humans. Clin. Exp. Allergy 39, 999-1008.
Srivastav, A., Kass, P. H., McGill, L. D., Farver, T. B., and Kent, M. S. (2012). Comparative vaccinespecific and other injectable-specific risks of injection-site sarcomas in cats. J. Am. Vet. Med. Assoc. 241, 595-602.

Ulanova, M., Tarkowski, A., HahnZoric, M., and Hanson, L. A. (2001). The Common vaccine adjuvant aluminum hydroxide up-regulates accessory properties of human monocytes via an interleukin4-dependent mechanism. Infect. Immun. 69, 1151-1159.

Vabulas, R. M., Ahmad-Nejad, P., Ghose, S., Kirschning, C. J., Issels, R. D., and Wagner, H. (2002). HSP70 as endogenous stimulus of the Toll/interleukin-1 receptor signal pathway. J. Biol. Chem. 277, 15107-15112.

Verdier, F., Burnett, R., MicheletHabchi, C., Moretto, P., FievetGroyne, F., and Sauzeat, E. (2005). Aluminium assay and evaluation of the local reaction at several time points after intramuscular administration of aluminium containing vaccines in the Cynomolgus monkey. Vaccine 23, 1359-1367.

Vessely, C., Estey, T., Randolph, T. W., Henderson, I., Cooper, J., Nayar, R., et al. (2009). Stability of a trivalent recombinant protein vaccine formulation against botulinum neurotoxin during storage in aqueous solution. J. Pharm. Sci. 98, 2970-2993.

Vessely, C., Estey, T., Randolph, T. W., Henderson, I., Nayar, R., and Carpenter, J. F. (2007). Effects of solution conditions and surface chemistry on the adsorption of three recombinant botulinum neurotoxin antigens to aluminum salt adjuvants. J. Pharm. Sci. 96, 2375-2389.

Volk, V. K., and Bunney, W. E. (1942). Diphtheria Immunization with fluid toxoid and alum-precipitated toxoid. Am. J. Public Health Nations Health 32, 690-699.

Wagner, L., Verma, A., Meade, B. D., Reiter, K., Narum, D. L., Brady, R. A., et al. (2012). Structural and immunological analysis of anthrax recombinant protective antigen adsorbed to aluminum hydroxide adjuvant. Clin. Vaccine Immunol. 19, 1465-1473.

Walls, R. S. (1977). Eosinophil response to alum adjuvants: involvement of $\mathrm{T}$ cells in non-antigen-dependent mechanisms. Proc. Soc. Exp. Biol. Med. 156, 431-435.

Wang, H. B., and Weller, P. F. (2008). Pivotal advance: eosinophils mediate early alum adjuvant-elicited B cell priming and IgM production. J. Leukoc. Biol. 83, 817-821.

Wang, Y., Kelly, C. G., Singh, M., McGowan, E. G., Carrara, A. S., Bergmeier, L. A., et al. (2002). Stimulation of Th1-polarizing cytokines, C-C chemokines, maturation of dendritic cells, and adjuvant function by the peptide binding fragment of heat shock protein 70. J. Immunol. 169, 2422-2429.

Wang, Y., Rahman, D., and Lehner, T. (2012). A comparative study of stress-mediated immunological functions with the adjuvanticity of alum. J. Biol. Chem. 287, 17152-17160.

Weissburg, R. P., Berman, P. W., Cleland, J. L., Eastman, D., Farina, F., Frie, S., et al. (1995). Characterization of the MN gp120 HIV-1 vaccine: antigen binding to alum. Pharm. Res. 12, 1439-1446.

Wherrett, D. K., Bundy, B., Becker, D. J., Dimeglio, L. A., Gitelman, S. E., Goland, R., et al. (2011) Antigen-based therapy with glutamic acid decarboxylase (GAD) vaccine in patients with recentonset type 1 diabetes: a randomised double-blind trial. Lancet 378, 319-327.

Wilcock, L. K., Francis, J. N., and Durham, S. R. (2004). Aluminium hydroxide down-regulates $\mathrm{T}$ helper 2 responses by allergen-stimulated human peripheral blood mononuclear cells. Clin. Exp. Allergy 34 1373-1378.

Willhite, C. C., Ball, G. L., and McLellan, C. J. (2012). Total allowable concentrations of monomeric inorganic aluminum and hydrated aluminum silicates in drinking water. Crit. Rev. Toxicol. 42, 358-442.

Wittayanukulluk, A., Jiang, D., Regnier, F. E., and Hem, S. L. (2004). Effect of microenvironment $\mathrm{pH}$ of aluminum hydroxide adjuvant on the chemical stability of adsorbed antigen. Vaccine 22, 1172-1176.

Wu, J. Y., Gardner, B. H., Murphy, C. I., Seals, J. R., Kensil, C. R., Recchia, J., et al. (1992). Saponin adjuvant enhancement of antigen-specific immune responses to an experimental HIV-1 vaccine. J. Immunol. 148, 1519-1525.
Xu, Z., Wang, Q., Zhuang, Y., Frederick, B., Yan, H., Bouman-Thio, E., et al. (2010). Subcutaneous bioavailability of golimumab at 3 different injection sites in healthy subjects. $J$. Clin. Pharmacol. 50, 276-284.

Yang, C. W., Strong, B. S., Miller, M. J., and Unanue, E. R. (2010). Neutrophils influence the level of antigen presentation during the immune response to protein antigens in adjuvants. J. Immunol. 185, 2927-2934.

Yoshimoto, T., Yasuda, K., Tanaka, H., Nakahira, M., Imai, Y., Fujimori, Y., et al. (2009). Basophils contribute to $\mathrm{T}(\mathrm{H}) 2-\mathrm{IgE}$ responses in vivo via IL-4 production and presentation of peptide-MHC class II complexes to CD4+ T cells. Nat. Immunol. 10 , 706-712.

Yu, D., Rao, S., Tsai, L. M., Lee, S. K., He, Y., Sutcliffe, E. L., et al. (2009). The transcriptional repressor Bcl-6 directs $\mathrm{T}$ follicular helper cell lineage commitment. Immunity 31, 457-468.

Zhang, J. G., Czabotar, P. E., Policheni, A. N., Caminschi, I., Wan, S. S., Kitsoulis, S., et al. (2012). The dendritic cell receptor Clec9A binds damaged cells via exposed actin filaments. Immunity 36, 646-657.

Zhu, J., Yamane, H., and Paul, W. E. (2010). Differentiation of effector CD4 T cell populations. Annu. Rev. Immunol. 28, 445-489.

Conflict of Interest Statement: The author declares that the research was conducted in the absence of any commercial or financial relationships that could be construed as a potential conflict of interest.

Received: 06 September 2012; accepted: 16 December 2012; published online: 10 January 2013.

Citation: HogenEsch H (2013) Mechanism of immunopotentiation and safety of aluminum adjuvants. Front. Immun. 3:406. doi: 10.3389/fimmu.2012.00406

This article was submitted to Frontiers in Immunotherapies and Vaccines, a specialty of Frontiers in Immunology.

Copyright (c) 2013 HogenEsch. This is an open-access article distributed under the terms of the Creative Commons Attribution License, which permits use, distribution and reproduction in other forums, provided the original authors and source are credited and subject to any copyright notices concerning any third-party graphics etc. 